\title{
Efficient treatment of aniline containing wastewater in bipolar membrane microbial electrolysis cell-Fenton system
}

\author{
Li, Xiaohu; Jin, Xiangdan; Zhao, Nannan; Angelidaki, Irini; Zhang, Yifeng
}

Published in:

Water Research

Link to article, DOI:

10.1016/j.watres.2017.04.047

Publication date:

2017

Document Version

Peer reviewed version

Link back to DTU Orbit

Citation $(A P A)$ :

Li, X., Jin, X., Żhao, N., Angelidaki, I., \& Zhang, Y. (2017). Efficient treatment of aniline containing wastewater in bipolar membrane microbial electrolysis cell-Fenton system. Water Research, 119, 67-72.

https://doi.org/10.1016/j.watres.2017.04.047

\section{General rights}

Copyright and moral rights for the publications made accessible in the public portal are retained by the authors and/or other copyright owners and it is a condition of accessing publications that users recognise and abide by the legal requirements associated with these rights.

- Users may download and print one copy of any publication from the public portal for the purpose of private study or research.

- You may not further distribute the material or use it for any profit-making activity or commercial gain

- You may freely distribute the URL identifying the publication in the public portal 


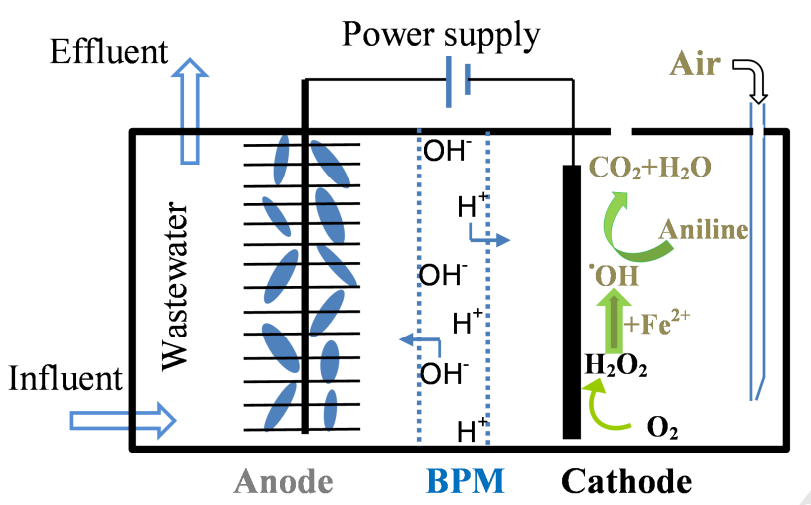


1 Submission to Water Research

2 Efficient treatment of aniline containing wastewater in bipolar membrane microbial electrolysis cell-Fenton system

$8 *$ Corresponding author:

9 Dr. Yifeng Zhang

10 Department of Environmental Engineering, Technical University of Denmark, Denmark

11 Tel: $(+45) 45251410$.

12 Fax: (+45) 45933850.

13 E-mail address: yifz@env.dtu.dk; yifzmfc@gmail.com 
21 Abstract

22 Aniline-containing wastewater can cause significant environmental problems and threaten

23 the humans's life. However, rapid degradation of aniline with cost-efficient methods remains

24 a challenge. In this work, a novel microbial electrolysis cell with bipolar membrane was

25 integrated with Fenton reaction (MEC-Fenton) for efficient treatment of real wastewater

26 containing a high concentration $\left(4460 \pm 52 \mathrm{mg} \mathrm{L}^{-1}\right)$ of aniline. In this system, $\mathrm{H}_{2} \mathrm{O}_{2}$ was in

27 situ electro-synthesized from $\mathrm{O}_{2}$ reduction on the graphite cathode and was simultaneously

28 used as source of ${ }^{\circ} \mathrm{OH}$ for the oxidation of aniline wastewater under an acidic condition

29 maintained by the bipolar membrane. The aniline was effectively degraded following first-

30 order kinetics at a rate constant of $0.0166 \mathrm{~h}^{-1}$ under an applied voltage of $0.5 \mathrm{~V}$. Meanwhile,

31 a total organic carbon (TOC) removal efficiency of $93.1 \pm 1.2 \%$ was obtained, revealing

32 efficient mineralization of aniline. The applicability of bipolar membrane MEC-Fenton

33 system was successfully demonstrated with actual aniline wastewater. Moreover, energy

34 balance showed that the system could be a promising technology for removal of

35 biorefractory organic pollutants from wastewaters.

36 Keywords: Microbial electrolysis cell; Fenton reaction; Aniline; Industrial wastewater;

37 Bipolar membrane; $\mathrm{H}_{2} \mathrm{O}_{2}$ 
43 Aniline $\left(\mathrm{C}_{6} \mathrm{H}_{5} \mathrm{NH}_{2}\right)$ has been widely used for various industries producing dyes, pesticides,

44 rubber chemicals, and pharmaceuticals. Considering the biological accumulation, long term 45 residue and carcinogenic properties, aniline-contained wastewater is categorized as 46 hazardous waste (Li et al., 2016a; Wang et al., 2016). Biological methods have been widely 47 used to treat aniline wastewater at low concentration $\left(0-1000 \mathrm{mg} \mathrm{L}^{-1}\right)$ (Jin et al., 2012; Liu et 48 al., 2015), during which the aniline can be completely mineralized into $\mathrm{CO}_{2}$ and $\mathrm{N}_{2} / \mathrm{NO}_{\mathrm{x}}$ 49 (Wang et al., 2016). However, most conventional biological methods cannot treat high 50 concentration $\left(>2000 \mathrm{mg} \mathrm{L}^{-1}\right)$ aniline wastewater due to the toxicity of aniline (Chen et al., 51 2007; Jin et al., 2012). In the past years, advanced oxidation processes especially the Electro-

52 Fenton process have been recognized as attractive method for aniline degradation due to its 53 high efficiency (Anotai et al., 2010; Brillas and Casado, 2002). However, there are still 54 several shortcomings such as high cost electrode materials, high electrical energy 55 consumption and required thoroughly $\mathrm{pH}$ control (at 2-3.5), which hinder industrial application ( Brillas et al., 2009).

57 Recently, Bio-Electro-Fenton systems such as integrated microbial fuel cell-Fenton systems (MFC-Fenton) and Microbial Electrolysis Cell-Fenton systems (MEC-Fenton) have been demonstrated as promising alternative and cost-effective methods to traditional Electro-

60 Fenton process for degradation of organic pollutants, such as azo dyes (Li et al., 2017b; 61 Zhang et al., 2015), P-nitrophenol (Tao et al., 2013), Estrone (Xu et al., 2013), Bisphenol A, 62 Sulfamethazine and Triclocarban (Wang et al., 2017). Though promising, there are still 63 challenges which need to be addressed and validation is needed before commercial 64 application. For instance, high mineralization efficiency has only been achieved with 
synthetic wastewater and/or at low pollutant concentration (Asghar et al., 2014; Xu et al., 2015). Furthermore, most of the bio-Electro-Fenton systems use cation exchange membrane $(\mathrm{CEM})$ as a separator, which has difficulty to maintain low catholyte $\mathrm{pH}$ and thus may cause inhibition on the Fenton process. The $\mathrm{pH}$ rise could also cause extensive iron precipitation which in return may damage the CEM and cathode (Ter Heijne et al., 2006). Therefore, a bio-Electro-Fenton system that can treat real and high concentration wastewater without causing $\mathrm{pH}$ issues is needed.

In this study, an innovative bio-Electro-Fenton system using bipolar membrane was developed to treat real industrial wastewater containing high concentration of aniline. The bipolar membrane has been shown to be an effective ion separator in previous MFC studies (Ter Heijne 2010), which could prevent $\mathrm{pH}$ elevation in the catholyte and $\mathrm{pH}$ drop in the anolyte (Ter Heijne et al., 2006; Ter Heijne et al., 2010; Zhang and Angelidaki, 2015). To the best of our knowledge, bipolar membrane has never been applied in bio-Electro-Fenton system. Furthermore, this is the first time that the MEC-Fenton system was applied for treatment of real industrial aniline wastewater. To optimize the conditions for the MECFenton degradation of aniline, the effects of $\mathrm{pH}$ value, air flow rate and applied voltage on aniline degradation were investigated. This work offers an efficient and cost-effective approach for the removal of biorefractory organic pollutants from industrial wastewaters.

\section{2. Material and methods}

\subsection{Reactor setup}

The schematic diagram of the bipolar membrane MEC-Fenton system is shown in Fig. 1. 
88 cathode $\mathrm{pH}$ and avoid $\mathrm{H}^{+}$leakage to the anode (Zhang et al., 2015). The working volume of

89 anode and cathode chamber was $100 \mathrm{~mL}(5 \mathrm{~cm} \times 5 \mathrm{~cm} \times 4 \mathrm{~cm})$. The anode electrode was

90 made of a carbon fiber brush (5.9 $\mathrm{cm}$ diameter, $6.9 \mathrm{~cm}$ length, Mill-Rose, USA), which was

91 pretreated at $450{ }^{\circ} \mathrm{C}$ for $30 \mathrm{~min}$ and then pre-cultivated with mature biofilm in a MFC reactor

92 before transferring to the MEC (Zhang et al., 2015). The cathode electrode was a graphite

93 plate $(3.5 \mathrm{~cm} \times 4 \mathrm{~cm})$. Cathode potential was measured versus a reference electrode

$94(\mathrm{Ag} / \mathrm{AgCl}$ electrode, $+197 \mathrm{mV}$ vs SHE). Titanium wire was used to connect the cathode and

95 anode electrode to the circuit.

\subsection{Characterization of domestic wastewater and aniline wastewater}

Domestic wastewater was collected from primary clarifier (Lyngby Wastewater Treatment

Plant, Copenhagen, Denmark). The characteristics of the wastewater were as following:

chemical oxygen demand (COD) of $386 \pm 32 \mathrm{mg} \mathrm{L}^{-1}, \mathrm{pH} 8.1$, conductivity of $1.7 \mathrm{mS} \mathrm{cm} \mathrm{c}^{-1}$,

stored at $4{ }^{\circ} \mathrm{C}$ before use. The aniline wastewater was provided by Vandrens A/S, Denmark

and then stored at $4{ }^{\circ} \mathrm{C}$ before use. The characteristics of the aniline wastewater were:

Aniline concentration of $4460 \pm 52 \mathrm{mg} \mathrm{L}^{-1}$, TOC of $3360 \pm 80 \mathrm{mg} \mathrm{L}^{-1}, \mathrm{COD}$ of $10930 \pm 110$

$\mathrm{mg} \mathrm{L}^{-1}$ and $\mathrm{pH}=7.2$. The aniline wastewater was amended with $50 \mathrm{mM} \mathrm{Na} 2 \mathrm{SO}_{4}$ and $10 \mathrm{mM}$

$105 \mathrm{FeSO}_{4}$ before each batch run.

\subsection{Reactor operation}

In this study, the research focused on the performance of aniline degradation in the cathode chamber. In order to avoid the influence from anode side, the anode chamber was continuously fed with domestic wastewater amended with sodium acetate $\left(\sim 1.6 \mathrm{~g} \mathrm{COD} \mathrm{L}^{-1}\right.$ in 
110 total) at $100 \mathrm{~mL} \mathrm{~d}^{-1}$. At the same time the domestic wastewater was recirculated from a feed reservoir (liquid volume of $300 \mathrm{~mL}$ ) through anode at a recirculation rate of $20 \mathrm{~mL} \mathrm{~min}{ }^{-1}$

112 using a peristaltic pump (OLE DICH, Instrument makers APS, Denmark). The anode

113 chamber and reservoir were purged with nitrogen gas before start new batch cycle. The

114 cathode chamber was filled with $80 \mathrm{~mL}$ aniline wastewater and operated in batch mode.

115 During the treatment process, fresh air was bubbled into the cathode providing oxygen at the

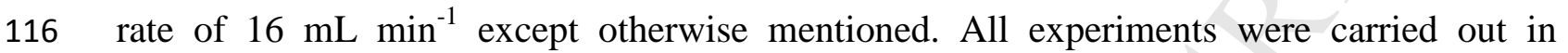
117 duplicate at ambient temperature $\left(20 \pm 2{ }^{\circ} \mathrm{C}\right)$. The cathode and anode were connected to a 118 battery test system (Neware Battery Testing System TC53, Shenzhen, China), which was 119 used as a power source (PS) to control the applied voltage and record the current of MEC (Li 120 et al., 2014).

\subsection{Analytical methods}

122 The samples were taken from the MEC cathode chamber, and then were filtered through $1230.45 \mu \mathrm{m}$ filters. The $\mathrm{H}_{2} \mathrm{O}_{2}$ concentration was measured by UV-vis spectrophotometry 124 (spectronic 20D+, Thermo Scientific) at $400 \mathrm{~nm}$, using potassium titanium (IV) oxalate as 125 colored indicator (Sellers, 1980). The concentration of aniline was determined by high 126 performance liquid chromatography (HPLC) (Wang et al., 2011). The pH was measured using a pH meter (PHM $210 \mathrm{pH}$ meter, Radiometer). Whereafter adding $1 \mathrm{M} \mathrm{NaOH}$ solution 128 in the samples to adjust the $\mathrm{pH}$ at 11 to stop the Fenton reaction. Chemical oxygen demand 129 (COD) was measured according to the standard method (A.W.W.A., 1998). The total organic 130 carbon (TOC) was measured by Shimadzu TOC 5000 A. Current density was calculated 131 based on the surface area of cathode. Energy consumption was mainly due to the pumping system besides power supply. The energy consumption for pumping system was estimated 
133 according to previous report (Zhang and Angelidaki, 2015). The calculations of degradation

134 rate constant of aniline (k), COD and TOC removal efficiencies are shown in the

135 Supplementary data.

\section{3. Results and discussion}

\subsection{Performance of aniline wastewater treatment in MEC-Fenton}

To evaluate the feasibility of this MEC-Fenton system for aniline wastewater treatment, aniline removal was conducted at $0.5 \mathrm{~V}, 16 \mathrm{~mL} \mathrm{~min}^{-1}$ air flow rate, $10 \mathrm{mM} \mathrm{Fe}^{2+}$ and initial $\mathrm{pH}$ 3. As shown in Fig. 2, aniline was rapidly degraded with removal efficiency of $97.1 \pm 1.2 \%$ in 6 days, while the removal efficiency was only $8 \%$ for the system without $\mathrm{Fe}^{2+}$ (Control 1) and $3 \%$ for the system without cathodic aeration (Control 2). The results imply that the bipolar membrane MEC-Fenton system was efficient for aniline degradation.

\section{Fig. 2. is here}

\subsection{Effect of initial $p H$}

The electro-Fenton processes are generally performed at low $\mathrm{pH}$ to avoid the precipitation of ferric hydroxides. This requires $\mathrm{pH}$ adjustment before and after wastewater treatment. To study the effect of wastewater $\mathrm{pH}$ on the aniline removal, a group of experiments were conducted under various initial $\mathrm{pH}$ values $(2,3,5$ and 7.2$)$ of aniline containing wastewater.

The results are illustrated in Fig. 3. Firstly, experiments were performed without any $\mathrm{pH}$ adjustment at 7.2 , which is the native $\mathrm{pH}$ value of aniline wastewater. The aniline removal 152 efficiency just was $8 \%$ at this $\mathrm{pH}$ value. Comparatively, decrease of the initial $\mathrm{pH}$ value from 1537.2 to 3 led to a sharp increase in the degradation efficiency of aniline. When the $\mathrm{pH}$ was decreased to 2 , the aniline degradation efficiency of $97.1 \pm 1.2 \%$ was obtained (Fig. 3a). The 
155 differences observed here may result from the different efficiency of Fenton reaction at different initial $\mathrm{pH}$ values. The results demonstrated the MEC-Fenton system constructed with bipolar membrane can be used to treat high concentration aniline wastewater efficiently with initial $\mathrm{pH} 2-3$.

The variation trend of catholyte $\mathrm{pH}$ is shown in Fig. 3b. It was observed that $\mathrm{pH}$ of aniline wastewater in the cathode chamber increased slowly to 5.6 from the initial value of 3 after 6 days treatment. The $\mathrm{pH}$ increased to 10.7 from the initial values of 5 and 7.2 after 6 days. In order to investigate the effect of bipolar membrane on the cathodic $\mathrm{pH}$, cation exchange membrane was used in a MEC as reference experiment, where the obvious removal of aniline was only observed for three days in MEC-Fenton with cation exchange membrane (Fig. S1. see Supplementary data). Furthermore, when using cation exchange membrane instead of bipolar membrane, ferric hydroxide was found in the cathode chamber after three days. The results demonstrated that the bipolar membrane could be used to help sustaining a lower catholyte $\mathrm{pH}$ without the need of extra acid dosage when the initial $\mathrm{pH}$ was 3 . On the other hand, the formation of short-chain carboxylic acids during the mineralization of aniline such as maleic acid and oxalic acid (Anotai et al., 2006) could also contribute to the acidic $\mathrm{pH}$. The anodic $\mathrm{pH}$ was maintained at 7.3-7.7 without significant changes. These results

172 further demonstrated that the bipolar membrane is an effective separator in MEC-Fenton 173 system.

\section{Fig. 3. is here}

\subsection{Effect of air flow rate}

176 The effect of air flow rate in the cathode on the degradation of aniline was investigated. It

177 can be seen in Fig. 4, the optimum air flow rate observed was $16 \mathrm{~mL} \mathrm{~min}^{-1}$. It could be due 
178 to that the increase of dissolved $\mathrm{O}_{2}$ and mass transfer rate in the aniline wastewater improved 179 the $\mathrm{H}_{2} \mathrm{O}_{2}$ production, and thus promoted the Electro-Fenton process. The decrease of aniline 180 decay rate at a higher air flow rate can be explained as following. There was a saturated state 181 for dissolved $\mathrm{O}_{2}$ in the MEC-Fenton system, thus the accumulations of $\mathrm{H}_{2} \mathrm{O}_{2}$ hardly 182 increased after dissolved $\mathrm{O}_{2}$ was saturated $\left(8.6 \pm 0.2 \mathrm{mg} \mathrm{L}^{-1}\right)$. In addition, the resistance of 183 the aniline wastewater also increased with the excessive mass of $\mathrm{O}_{2}$ bubble in the cathode 184 chamber, which could lead the less negative cathode potential (Fig. S2). As a result, slightly 185 drop in the removal efficiency of aniline was observed at the higher air flow rate. Similar 186 phenomena were observed in the Electro-Fenton system (Zhou et al., 2013). The trend of 187 COD and TOC removal efficiency in Fig. 4b was consistent with the evolution of aniline 188 concentration. The mineralization rate at $4,8,16$ and $50 \mathrm{~mL} \mathrm{~min}^{-1}$ was $43.5 \pm 2.3 \%, 68.2 \pm$ $1891.8 \%, 93.1 \pm 1.2 \%$ and $83.9 \pm 1.9 \%$ after 6 days, respectively. Moreover, the air flow rates could also affect the energy consumption in terms of pumping. These results indicated that setting an optimum air flow rate in the MEC-Fenton system could not only improve the 192 treatment efficiency of the aniline wastewater but also reduce treatment cost.

\section{Fig. 4. is here}

\subsection{Effect of applied voltage}

Applied voltage is a critical parameter affecting the effectiveness of Electro-Fenton process as it controls the production of hydroxyl radicals. Therefore its influence on the degradation of aniline in the MEC-Fenton system was investigated under the optimal air flow rate of 16 $\mathrm{mL} \min ^{-1}$ and initial $\mathrm{pH}$ 3. As shown in Fig. 5, aniline removal efficiency was significantly enhanced when the applied voltage was increased from 0.3 to $0.5 \mathrm{~V}$. However, further increase of applied voltage to $0.7 \mathrm{~V}$ led significantly in decrease of the aniline removal 
201 efficiency, which was probably due to the relatively faster increase of $\mathrm{pH}$ in the cathode (Fig.

$202 \mathrm{~S} 3$ ). In addition, the current density increased from $1.47 \pm 0.03$ to $3.35 \pm 0.03 \mathrm{~A} \mathrm{~m}^{-2}$ with the

203 increasing of applied voltage from 0.3 to $0.7 \mathrm{~V}$ (Fig. $5 \mathrm{~b}$ ). The cathode potential was $-0.31 \pm$ $0.01,-0.45 \pm 0.01$ and $-0.60 \pm 0.02 \mathrm{~V}$ at $0.3,0.5$ and $0.7 \mathrm{~V}$ (Fig. 5c), respectively. The corresponding COD removal efficiencies are presented in Fig. 5d. Similar behavior of aniline removal efficiencies under different applied voltages were observed. The trend was different with Electro-Fenton processes for aniline wastewater treatment. It could be due to that the performance of Electro-Fenton for pollutants degradation was highly dependent on the $\mathrm{H}_{2} \mathrm{O}_{2}$ production rate and hydroxyl radical $\left({ }^{\circ} \mathrm{OH}\right)$ generation from the reaction between $\mathrm{Fe}^{2+}$ and $\mathrm{H}_{2} \mathrm{O}_{2}$ (Eq. 1). The $\bullet \mathrm{OH}$ generation rate would increase with the increasing of $\mathrm{H}_{2} \mathrm{O}_{2}$ production rate. According to our previous study (Li et al., 2017a), the optimal cathode potential of the graphite plate for $\mathrm{H}_{2} \mathrm{O}_{2}$ production is ranging from $-0.4 \mathrm{~V}$ to $-0.5 \mathrm{~V}$. Thus, the applied voltage of $0.5 \mathrm{~V}$ was the optimal for the aniline degradation in the bipolar membrane MEC-Fenton system.

$$
\mathrm{Fe}^{2+}+\mathrm{H}_{2} \mathrm{O}_{2}+\mathrm{H}^{+} \rightarrow \mathrm{Fe}^{3+}+{ }^{\bullet} \mathrm{OH}+\mathrm{H}_{2} \mathrm{O}
$$

Mineralization of organic pollutants with fast kinetics is highly desirable for contamination control. Here, the TOC removal efficiency was tested to evaluate the performance of MEC-Fenton for aniline mineralization (Fig. 5d). The TOC removal efficiency was $66.8 \pm 3.1,93.1 \pm 1.2,51.2 \pm 1.9 \%$ at $0.3,0.5$ and $0.7 \mathrm{~V}$ after 6 days, respectively. The higher mineralization rate of aniline at $0.5 \mathrm{~V}$ could be due to the faster $\mathrm{H}_{2} \mathrm{O}_{2}$ production rate which is dependent mainly on the cathode electrode potential regulated by the external applied voltage. The results are similar with the trend of aniline removal efficiency. The removal rate constant of aniline degradation was $0.0097,0.0166$ and 0.0066 
$224 \mathrm{~h}^{-1}$ at $0.3,0.5$ and $0.7 \mathrm{~V}$, respectively (Fig. S4). These results imply that aniline can be

225 efficiently mineralized by the MEC-Fenton technology at $0.5 \mathrm{~V}$. This behavior can be

226 ascribed to the greater production rate of $\mathrm{H}_{2} \mathrm{O}_{2}$ at $0.5 \mathrm{~V}$. The residual $\mathrm{H}_{2} \mathrm{O}_{2}$ in the treated

227 aniline wastewater at different applied voltage were also measured (Fig. S5). The residual

$228 \mathrm{H}_{2} \mathrm{O}_{2}$ concentration after MEC-Fenton treatment was less than $10 \mathrm{mg} \mathrm{L}^{-1}$. The results also

229 demonstrated the feasibility of the bipolar membrane MEC-Fenton system for efficient

230 control of residual $\mathrm{H}_{2} \mathrm{O}_{2}$ level during aniline wastewater treatment.

Fig. 5. is here

\subsection{Energy efficiency for aniline wastewater treatment}

233 Energy consumption is one of the major concerns for wastewater treatment using Electro234 Fenton technology, especially for recalcitrant pollutant degradation. In this bipolar 235 membrane MEC-Fenton process, the optimal external voltage for aniline wastewater 236 treatment was $0.5 \mathrm{~V}$, which was much lower than that required for conventional Electro237 Fenton process. The costs of the MEC-Fenton system mainly include the capital costs and 238 the operating costs. The bipolar membrane MEC reactor capital costs are approx. $5544 € \mathrm{~m}^{-3}$ 239 (in Denmark) (Zhang and Angelidaki, 2016). The operating costs mainly include reagent 240 costs and energy consumption of the external power supply. The MEC-Fenton system 241 degrade aniline only required energy consumption of $0.728 \mathrm{kWh} \mathrm{kg}^{-1}$-aniline from the 242 external power over a fed batch cycle, which was much lower than classical Electro-Fenton 243 process treat aniline with a cost of $74 \mathrm{kWh} \mathrm{kg}^{-1}$-aniline (Brillas and Casado, 2002). The 244 energy consumption for pumping would be $0.374 \mathrm{kWh} \mathrm{kg}^{-1}$-aniline. Meanwhile our 245 estimates were based on small laboratory-scale reactor and did not include reagent, e.g., 
$246 \mathrm{Na}_{2} \mathrm{SO}_{4}, \mathrm{FeSO}_{4}$. Nevertheless the above results suggest that the bipolar membrane MEC-

247 Fenton system was a cost-effective method for aniline wastewater treatment.

\subsection{Perspectives}

The results in this study demonstrated that the bipolar membrane MEC-Fenton system was environment-friendly, efficient and low cost compared to conventional Electro-Fenton system. In this process, the MEC besides treating domestic wastewater in the anode chamber (the COD removal efficiency reached $80.5 \pm 2.2 \%$ under $0.5 \mathrm{~V}$ ), also mineralizes aniline from wastewater in the cathode chamber. It was proven that the operation of bipolar membrane MEC-Fenton greatly enhanced the treatment of aniline wastewater. Compared to other bio-Electro-Fenton system such as MFC-Fenton system, the bipolar membrane MECFenton system has its own merits. Firstly, the degradation efficiency was greatly improved by adding low applied voltage (0.5 V) compared to MFC (Zhang et al., 2015). Secondly, the MEC-Fenton reactor with bipolar membrane requires lower dose of acid to adjust and control the $\mathrm{pH}$ of the aniline wastewater. Thirdly, the energy consumption was only 1.423 $\mathrm{kWh} \mathrm{kg}^{-1}$-TOC under optimal operation condition, which was much lower than that in Electro-Fenton process (45.8 $\mathrm{kWh} \mathrm{kg}^{-1}$-TOC) (Gao et al., 2015). In addition, compared with other methods for aniline removal (see table 1), the MEC-Fenton system has relative high removal rate, especially higher than that of the biodegradation method. All these advantages together suggest that the MEC-Fenton system has potential for cost-effective and efficient degradation of recalcitrant organic pollutants. Finally, this system also can be extended to treat other industrial wastewater such as pharmaceuticals wastewaters. Though promising, more efforts should be made to accelerate the industrial application, such as development of large scale system with continues-flow operation. Future work also should focus on the 
269 development of low cost cathode electrode with large surface such as three dimensional

270 electrode, which may improve the $\mathrm{H}_{2} \mathrm{O}_{2}$ production rate and further enhance the aniline

271 removal rate.

\section{4. Conclusions}

273 This study demonstrated that the MEC-Fenton system is an effective and environmentally

274 friendly technology for aniline containing wastewater treatment. In such system, high

275 concentration $\left(4460 \pm 52 \mathrm{mg} \mathrm{L}^{-1}\right)$ aniline was not only effectively degraded with removal 276 rate of $30.1 \pm 0.4 \mathrm{mg} \mathrm{L}^{-1} \mathrm{~h}^{-1}$, but also highly mineralized with TOC removal efficiency of $27793.1 \pm 1.2 \%$ and $\mathrm{k}$ of $0.0166 \mathrm{~h}^{-1}$ at initial $\mathrm{pH} 3$. Notably the energy consumption was only

$2781.423 \mathrm{kWh} \mathrm{kg}^{-1}$-TOC. This work provides a cost-effective method for aniline degradation,

279 which is also attractive and applicable for efficient treatment of industrial wastewater.

\section{Acknowledgments}

281 The authors would like to acknowledge financial support from the China Scholarship 282 Council and the technical assistance by Hector Garcia with analytical measurements. This research was supported financially by The Danish Council for Independent Research (DFF1335-00142).

\section{References}

American Public Health Association, A.W.W.A.Water Pollution Control Federation, 1998. Standard Methods for the Examination of Water and Wastewater, nineteenth. American Public Health Association, Washington, DC.

Anotai, J., Lu, M.C. and Chewpreecha, P., 2006. Kinetics of aniline degradation by Fenton and electro-Fenton processes. Water Res. 40(9), 1841-1847. oxidation by electro-Fenton and fluidized-bed Fenton processes. J. Hazard. Mater. 183 (1- 
3), 888-893.

Asghar, A., Abdul Raman, A.A. and Daud, W.M.A.W., 2014. Recent advances, challenges and prospects ofin situproduction of hydrogen peroxide for textile wastewater treatment in microbial fuel cells. Journal of Chemical Technology \& Biotechnology 89(10), 1466-1480.

Chen, S., Sun, D. and Chung, J.S., 2007. Anaerobic treatment of highly concentrated aniline wastewater using packed-bed biofilm reactor. Process Biochem. 42(12), 1666-1670.

Cheng, H.Y., Liang, B., Mu, Y., Cui, M.H., Li, K., Wu, W.M. and Wang, A.J., 2015. Stimulation of oxygen to bioanode for energy recovery from recalcitrant organic matter aniline in microbial fuel cells (MFCs). Water Res 81, 72-83.

Brillas, E., Sires, I., Oturan, M. A., 2009. Electro-Fenton Process and Related Electrochemical Technologies Based on Fentons Reaction Chemistry. Chem. Rev. 109, 6570-6631.

Brillas, E., Casado, J., 2002. Aniline degradation by Electro-Fenton and peroxi-coagulation processes using a flow reactor for wastewater treatment. Chemosphere 47, 241-248.

Gao, G., Zhang, Q., Hao, Z. and Vecitis, C.D., 2015. Carbon nanotube membrane stack for flow-through sequential regenerative electro-Fenton. Environ. Sci. Technol. 49(4), 23752383.

Jin, Q., Hu, Z., Jin, Z., Qiu, L., Zhong, W. and Pan, Z., 2012. Biodegradation of aniline in an alkaline environment by a novel strain of the halophilic bacterium, Dietzia natronolimnaea JQ-AN. Bioresour. Technol. 117, 148-154.

Li, X.H., Liang, D.W., Bai, Y.X., Fan, Y.T. and Hou, H.W., 2014. Enhanced $\mathrm{H}_{2}$ production from corn stalk by integrating dark fermentation and single chamber microbial electrolysis cells with double anode arrangement. Int. J. Hydrogen Energy 39(17), 8977-8982.

Li, X., Angelidaki, I. and Zhang, Y., 2017a. Salinity-gradient energy driven microbial electrosynthesis of hydrogen peroxide. J. Power Sources 341, 357-365.

Li, X., Jin, X., Zhao, N., Angelidaki, I. and Zhang, Y., 2017b. Novel bio-electro-Fenton technology for azo dye wastewater treatment using microbial reverse-electrodialysis electrolysis cell. Bioresour. Technol. 228, 322-329.

Li, X., Xu, H. and Yan, W., 2016a. Electrochemical oxidation of aniline by a novel Ti/TiOxHy/Sb-SnO2 electrode. Chinese J. Catal. 37(11), 1860-1870.

Li, X., Xu, H., Yan, W. and Shao, D., 2016b. Electrocatalytic degradation of aniline by $\mathrm{Ti} / \mathrm{Sb}-\mathrm{SnO} 2, \mathrm{Ti} / \mathrm{Sb}-\mathrm{SnO} 2 / \mathrm{Pb} 3 \mathrm{O} 4$ and $\mathrm{Ti} / \mathrm{Sb}-\mathrm{SnO} 2 / \mathrm{PbO} 2$ anodes in different electrolytes. 
J. Electroanal. Chem. 775, 43-51.

Liu, Y.B., Qu, D., Wen, Y.J. and Ren, H.J., 2015. Low-temperature biodegradation of aniline by freely suspended and magnetic modified Pseudomonas migulae AN-1. Appl. Microbiol Biot. 99(12), 5317-5326.

Sellers, R.M.,1980. Spectrophotometric Determination of Hydrogen Peroxide Using Potassium Titanium( IV) Oxalate. Analyst 105, 950-954.

Tao, H.C., Wei, X.Y., Zhang, L.J., Lei, T. and Xu, N., 2013. Degradation of p-nitrophenol in a BES-Fenton system based on limonite. J. Hazard. Mater. 254-255, 236-241.

Ter Heijne, A., Hamelers, H. V. M., De Wilde, V., Rozendal, R. A., Buisman, C. J. N., 2006. A Bipolar Membrane Combined with Ferric Iron Reduction as an Efficient Cathode System in Microbial Fuel Cells. Environ. Sci. Technol. 40, 5200-5205.

Ter Heijne, A., Liu, F., Weijden R.V.D., Weijma, J., Buisman, C. J. N., Hamelers, H. V. M., De Wilde, V., 2010. Copper Recovery Combined with Electricity Production in a Microbial Fuel Cell. Environ. Sci. Technol. 44, 4376-4381.

Wang, A.J., Cheng, H.Y., Liang, B., Ren, N.Q., Cui, D., Lin, N., Kim, B.H. and Rabaey, K., 2011. Efficient reduction of nitrobenzene to aniline with a biocatalyzed cathode. Environ. Sci. Technol. 45(23), 10186-10193.

Wang, Q., Jiang, C., Wang, Y., Yang, Z. and Xu, T., 2016. Reclamation of Aniline Wastewater and $\mathrm{CO}_{2}$ Capture Using Bipolar Membrane Electrodialysis. ACS Sustainable Chem. Eng. 4(10), 5743-5751.

Wang, Y., Feng, C., Li, Y., Gao, J. and Yu, C.P., 2017. Enhancement of emerging contaminants removal using Fenton reaction driven by $\mathrm{H}_{2} \mathrm{O}_{2}$-producing microbial fuel cells. Chem. Eng. J. 307, 679-686.

Xu, N., Zeng, Y., Li, J., Zhang, Y. and Sun, W., 2015. Removal of 17ß-estrodial in a bioelectro-Fenton system: contribution of oxidation and generation of hydroxyl radicals with the Fenton reaction and carbon felt cathode. RSC Adv. 5(70), 56832-56840.

Xu, N., Zhang, Y., Tao, H., Zhou, S. and Zeng, Y., 2013. Bio-electro-Fenton system for enhanced estrogens degradation. Bioresour. Technol. 138, 136-140.

Zhang, Y. and Angelidaki, I., 2015. Recovery of ammonia and sulfate from waste streams and bioenergy production via bipolar bioelectrodialysis. Water Res. 85, 177-184.

Zhang, Y. and Angelidaki, I., 2016. Microbial Electrochemical Systems and Technologies: It Is Time To Report the Capital Costs. Environ. Sci. Technol. 50(11), 5432-5433. 
Zhang, Y., Wang, Y. and Angelidaki, I., 2015. Alternate switching between microbial fuel cell and microbial electrolysis cell operation as a new method to control $\mathrm{H}_{2} \mathrm{O}_{2}$ level in Bioelectro-Fenton system. J. Power Sources 291, 108-116.

Zhou, L., Zhou, M., Zhang, C., Jiang, Y., Bi, Z. and Yang, J., 2013. Electro-Fenton degradation of p-nitrophenol using the anodized graphite felts. Chem. Eng. J. 233, 185192. 
Table 1. Performance of aniline removal using different technologies.

\begin{tabular}{llllll}
\hline Method & $\begin{array}{l}\text { Concentration } \\
\left(\mathrm{mg} \mathrm{L}^{-1}\right)\end{array}$ & $\begin{array}{l}\text { Removal } \\
\text { efficiency }\end{array}$ & $\begin{array}{l}\text { Removal rate } \\
\left(\mathrm{mg} \mathrm{L}^{-1} \mathrm{~h}^{-1}\right)\end{array}$ & $\begin{array}{l}\text { Energy consumption } \\
\mathrm{kWh} \mathrm{kg}^{-1} \text {-aniline }\end{array}$ & Reference \\
\hline Fenton & 930 & $85.9 \%$ & 798.9 & - & (Anotai et al., 2006) \\
Electro-Fenton & 1000 & $63 \%$ & 315 & 74 & (Brillas and Casado, 2002) \\
Biodegradation & 300 & $87 \%$ & 2.175 & - & (Jin et al., 2012) \\
Fluidized-bed Fenton & 930 & $97 \%$ & 1804.2 & - & (Anotai et al., 2010) \\
MFC-biodegradation & $260.4 \pm 9.3$ & $91.2 \pm 2.2 \%$ & $1.65 \pm 0.04$ & - & (Cheng et al., 2015) \\
Electrocatalytic & 3500 & $97.7 \%$ & 683.9 & 36.2 & (Li et al., 2016b) \\
Electrodialysis & 1000 & $100 \%$ & 6792.4 & 2.86 & (Wang et al., 2016) \\
MEC-Fenton & $4460 \pm 52$ & $97.1 \pm 1.2 \%$ & $30.1 \pm 0.4$ & 1.10 & This study \\
\hline
\end{tabular}


411 Fig. 1. Schematic illustration of the MEC-Fenton reactor with bipolar membrane (BPM).

412 Fig. 2. The performance of bipolar membrane MEC-Fenton system on the aniline

413 degradation. Conditions: $\mathrm{E}=0.5 \mathrm{~V}$, initial $\mathrm{pH}=3$ and air flow rate of $16 \mathrm{~mL} \mathrm{~min}^{-1}$. (Control

414 1: without $\mathrm{Fe}^{2+}$; Control 2: without cathodic aeration)

415 Fig. 3. The effect of initial $\mathrm{pH}$ on the performance of bipolar membrane MEC-Fenton

416 system. Conditions: $\mathrm{E}=0.5 \mathrm{~V}$, air flow rate of $16 \mathrm{~mL} \mathrm{~min}^{-1}$.

417 Fig. 4. The effect of air flow rate on the performance of bipolar membrane MEC-Fenton

418 system. Conditions: $\mathrm{E}=0.5 \mathrm{~V}$, initial $\mathrm{pH}=3$.

419 Fig. 5. The effect of applied voltage on the bipolar membrane MEC-Fenton degradation of 420 aniline. 


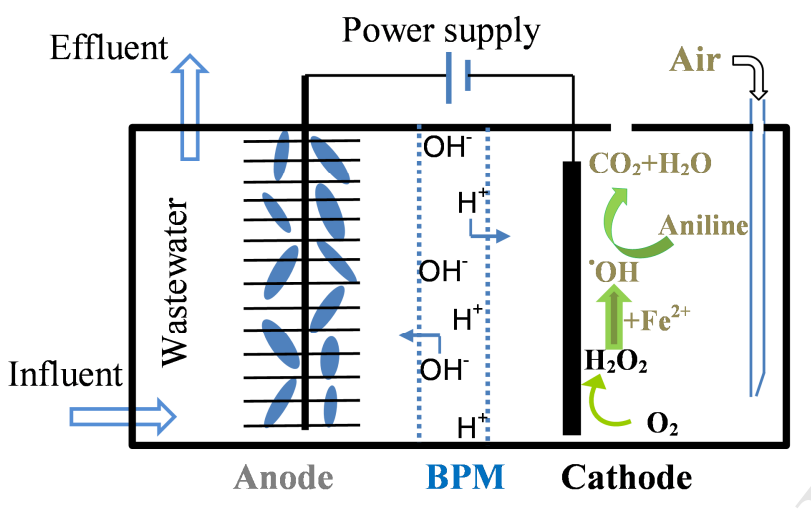

Fig. 1. 


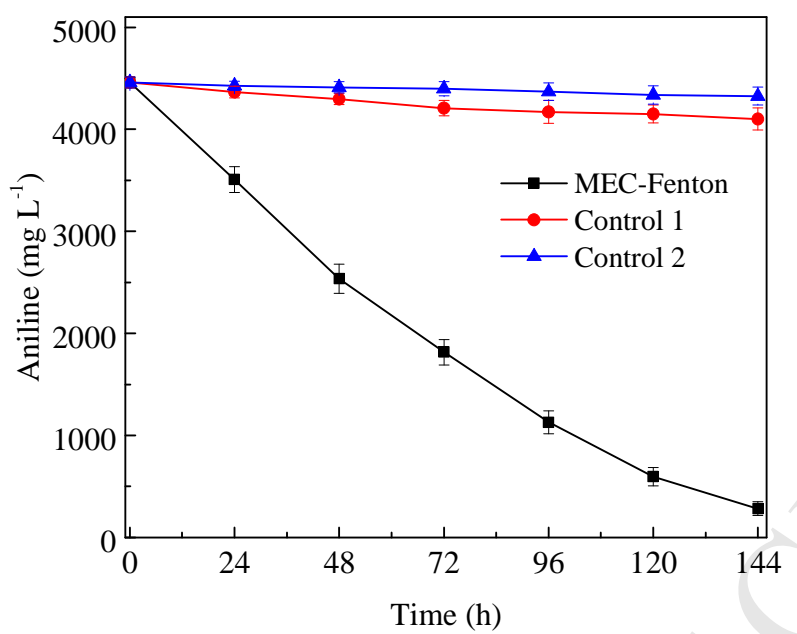

Fig. 2. 

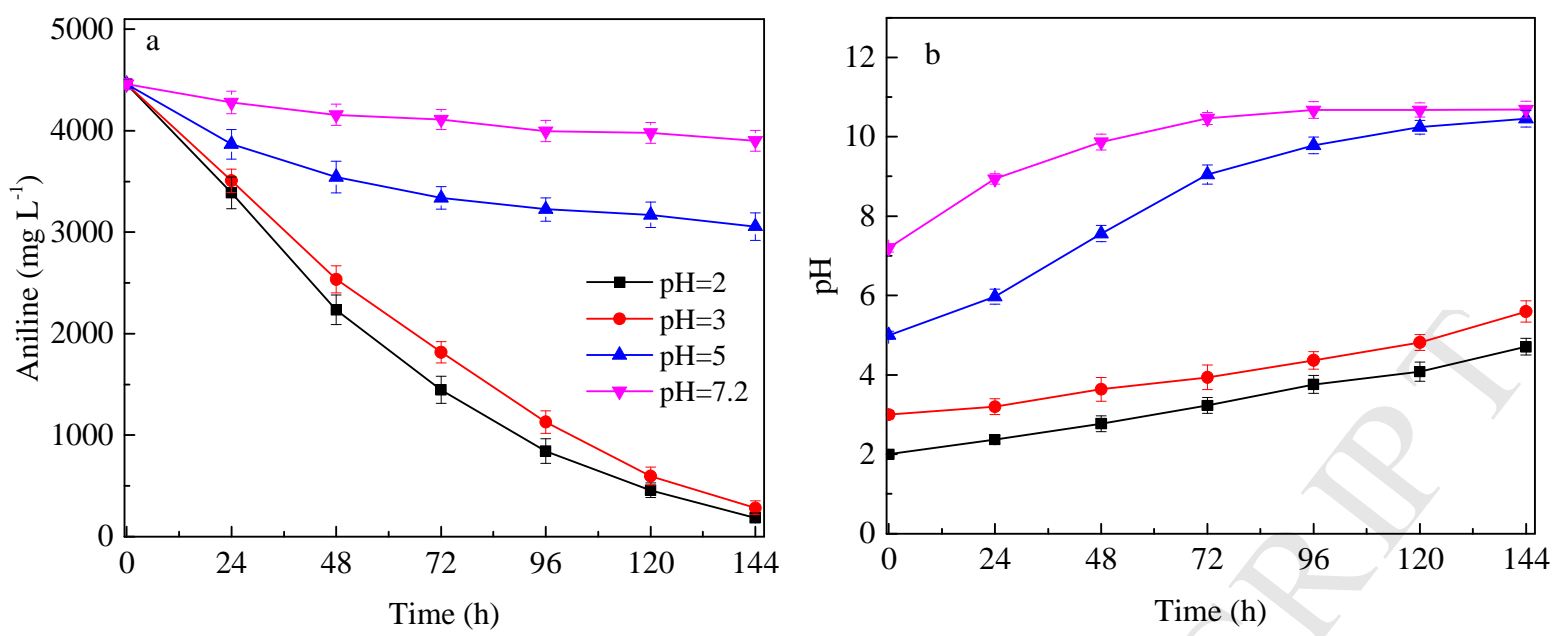

Fig. 3. 

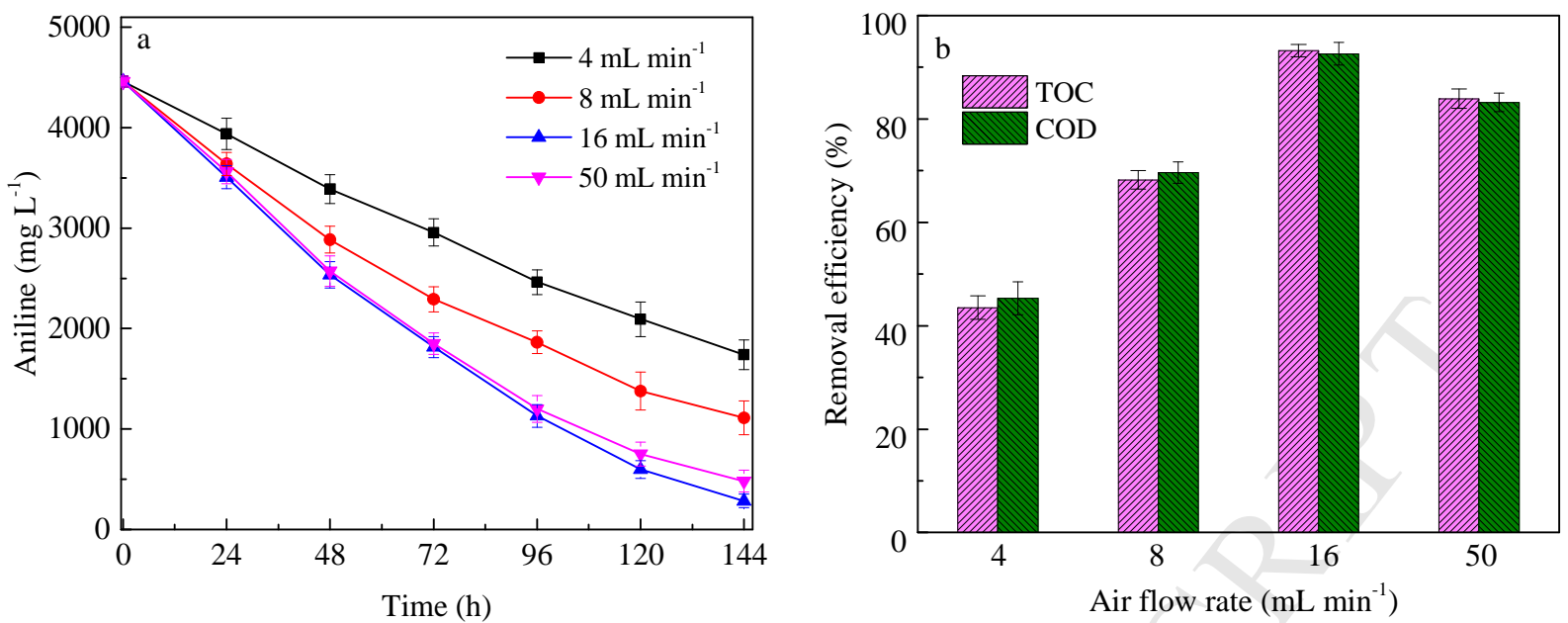

Fig. 4. 

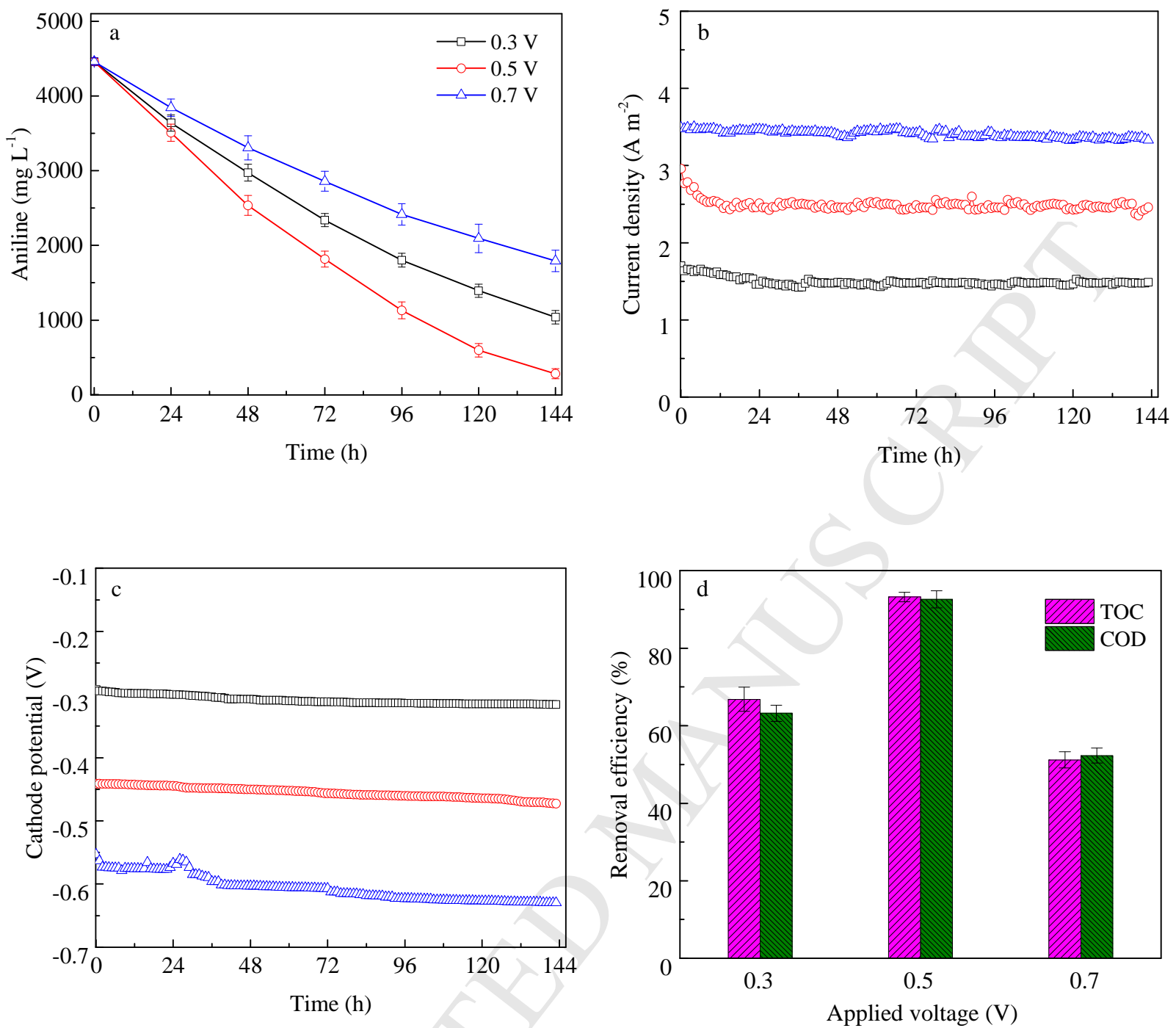

Fig. 5. 


\section{Highlights}

- Novel MEC-Fenton process for the treatment of real aniline-contained wastewater.

- The bipolar membrane was an effective $\mathrm{pH}$ separator in MEC-Fenton process.

- High removal efficiency was achieved at relatively higher aniline concentration.

- Identified key factors affecting the aniline degradation in MEC-Fenton system.

- Efficient removal of aniline with low energy consumption in MEC-Fenton system. 